\title{
Wpływ temperatury procesu zgrzewania tarciowego z przemieszaniem - FSW - na wytrzymałość złącza
}

\author{
Influence of temperature of friction stir welding process \\ with mixing - FSW - on the strength of the weld
}

\section{Streszczenie}

Stosowanie podgrzewania prowadzi do niwelacji odkształceń plastycznych zgrzewanych cienkościennych blach metodą FSW. Podgrzewanie to podwyższa temperaturę procesu, umożliwiając stosowanie większych prędkości posuwowych, a co za tym idzie - skraca jego czas. Badania złącza wykonanego przy jednakowych parametrach wykazały znacznie większą wytrzymałość na rozciąganie w przypadku zgrzewania z zastosowaniem podgrzewania. Badania przeprowadzone kamerą termowizyjną ukazały proces rozchodzenia się ciepła. Zauważono, że temperatura w początkowych fazach zgrzewania jest znacznie niższa, co bez wątpienia powoduje powstawanie złącza o niższej wytrzymałości.

Słowa kluczowe: zgrzewanie tarciowe z przemieszaniem; wytrzymałość złącza FSW; połączenie zakładkowe; zgrzewanie aluminium; podgrzewanie podczas FSW

\section{Abstract}

The use of heating leads to reducing plastic deformations of thin sheets welded by the FSW method. Preheating increases the process temperature and allows higher feed rates to be used, thus reducing the time of the process. Tests made on connections with the same parameters showed much higher tensile strength in the case of using heating. Thermal imaging studies have shown the heat dissipation process and it has been noticed that the initial temperature is significantly lower, which undoubtedly results in the formation of a lower strength weld.

Keywords: Friction Stir Welding; FSW connection strength; overlapping connection; aluminum welding; FSW with heating

\begin{abstract}
Wstęp
Metoda zgrzewania tarciowego z przemieszaniem (ang. Friction Stir Welding - FSW) jest obecnie jedną z metod, nad którą prowadzone są liczne badania spajania w stanie stałym. Zastosowanie tej technologii umożliwia łączenie metali uważanych za niespawalne. Do takich metali zalicza się stop aluminium 2024, który w swym składzie posiada $3,80 \div 4,90 \%$ Cu, a co za tym idzie wykazuje wysoką skłonność do powstawania pęknięć podczas procesu spawania. W przemyśle lotniczym stop ten powszechnie stosowany jest po procesie utwardzania wydzieleniowego, co ze względu na wysokie temperatury procesu oraz przemiany, które osłabiłyby znacznie materiał łączony, dyskwalifikuje metode spawania. W postaci blach o grubości $0,6 \div 1 \mathrm{~mm}$ stop 2024 w stanie T351 wykorzystuje się jako materiał na pokrycia samolotów. Proces Friction Stir Welding zachodzi poniżej temperatury topnienia, dlatego też z powodzeniem może być on stosowany do spajania tego typu materiałów. Obecnie do łączenia struktur lotniczych wykorzystuje się dość pracochłonną i kosztowną metodę nitowania. Metoda FSW
\end{abstract}

jest alternatywą do tego typu zadań, która wymaga dokładnego przebadania procesu i zjawisk, jakie zachodzą podczas procesu. Zgrzewanie tarciowe z przemieszaniem struktur cienkościennych niesie ze sobą kilka problemów, do których zalicza się m.in. powstawanie deformacji. Po wstępnej analizie procesu stwierdzono, że jedną z przyczyn powstawania odkształceń blach są duże gradienty temperaturowe. W celu zmniejszenia różnic temperaturowych w materiale łączonym zaprojektowano uchwyt podgrzewający zgrzewane blachy. Jak się spodziewano, zabieg ten zmniejszył odkształcenia zgrzewanych blach, a także wpłynął znacząco na własności wytrzymałościowe złącza.

\section{Charakterystyka procesu FSW}

Proces zgrzewania tarciowego z przemieszaniem polega na wprowadzeniu rotującego narzędzia w materiał zgrzewany i przesuwaniu go wzdłuż linii styku (rys. 1). Podczas procesu

Inż. Krzysztof Ochałek - Państwowa Wyższa Szkoła Zawodowa w Krośnie.

Autor korespondencyjny/Corresponding author. krzysiekochalek14@interia.pl 


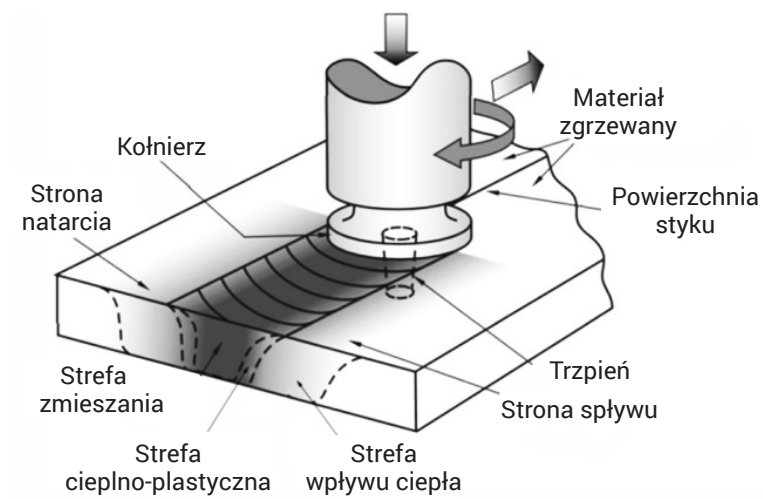

Rys. 1. Schemat procesu FSW [2]

Fig. 1. Scheme of the FSW process [2]

spajania, aby przebiegł on pomyślnie, konieczne jest sztywne zamocowanie i dociśnięcie do siebie łączonych elementów. Specjalne narzędzie, obracając się wskutek tarcia oraz mechanicznego mieszania materiału, wytwarza ciepło, skutkiem czego jest uplastycznienie zgrzewanego materiału, który bez problemu może zostać przemieszany.

Ilość ciepła konieczna do zajścia procesu FSW jest znacznie niższa, aniżeli podczas spawania tradycyjnego. Stosując metodę zgrzewania tarciowego z przemieszaniem możliwe jest uniknięcie tworzenia się niekorzystnych faz osłabiających materiał spajany. Naprężenia termiczne są również znacznie mniejsze, jednakże w obydwu przypadkach nie jest możliwe ich całkowite wyeliminowanie. Mikrostruktura złącza wykonanego metodą FSW jest drobnoziarnista i zasadniczo pozbawiona pęknięć, które występują bardzo często podczas spawania [4,6]. Efektywność połączenia określana jako stosunek wytrzymałości materiału spajanego metodą FSW do wytrzymałości materiału rodzimego, w przypadku próby rozciągania osiąga do 96\% [3].

\section{Ciepło procesu}

Ciepło podczas procesu FSW powstaje wskutek tarcia pomiędzy narzędziem a zgrzewanym materiałem. Podstawą dobrze wykonanej zgrzeiny jest dobór odpowiednich parametrów zgrzewania, które bezpośrednio wpływają na ciepło procesu, a co za tym idzie - na budowę, a także własności wytrzymałościowe złącza. Dla narzędzia o trzpieniu walcowym przedstawionym na rysunku 2 wartość momentu tarcia można wyliczyć z zależności 1 (gdzie: $\mu$ - współczynnik tarcia między narzędziem, a materiałem zgrzewanym). Korzystając ze wzoru 2., znając prędkość obrotową - n i prędkość zgrzewania $-v_{z}$, można wyliczyć energię jednostkową w punkcie [1].

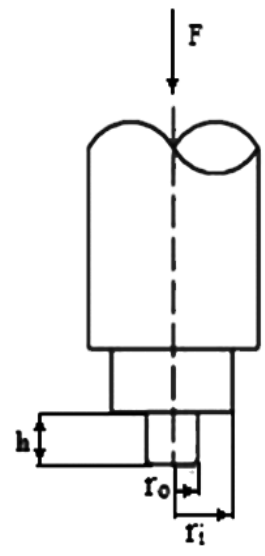

Rys. 2. Schemat narzędzia

Fig. 2. Scheme of the tool

$$
\begin{aligned}
& M_{t}=2 \mu \cdot F\left(\frac{r_{0}}{3}+\frac{r_{i}^{2}}{r_{0}^{2}} \cdot h\right) \\
& E=M_{t} \cdot n / v_{z}
\end{aligned}
$$

Interpretując powyższe wzory można zauważyć, że największy wpływ na ilość generowanego ciepła ma prędkość obrotową oraz prędkość posuwu. Stosując większe prędkości obrotowe zwiększa się ilość generowanego ciepła, zwiększając natomiast posuw wydziela się mniejsza jego ilość. Dobranie nieodpowiedniej prędkości obrotowej i posuwowej skutkować może wystąpieniem lokalnych nadtopień łączonych elementów. Może to doprowadzić do utraty jednorodności złącza, wpłynąć na strukturę złącza oraz skutkować powstaniem wydzieleń osłabiających zgrzane elementy. Przypadek nadtopienia materiału łączonego ma miejsce, gdy zastosuje się zbyt wysokie prędkości obrotowe i niskie prędkości posuwowe (rys. 3).

Podczas zgrzewania, stosując równocześnie duże prędkości obrotowe i posuwowe, może dojść do powstania pustek oraz lokalnych nieciągłości zgrzeiny (rys. 4).

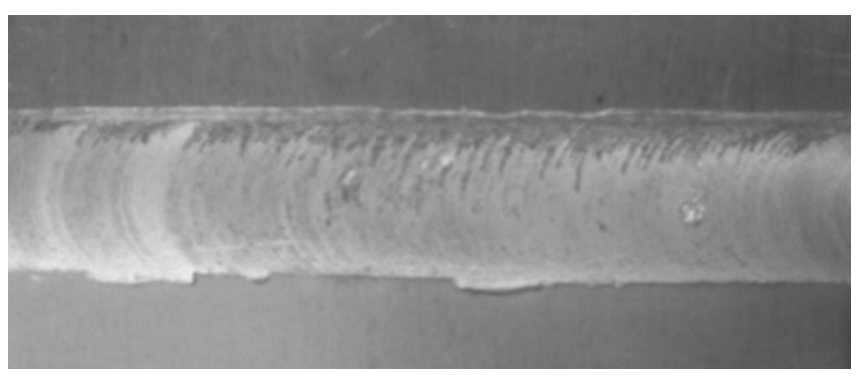

Rys. 3. Nadtopiona powierzchnia zgrzeiny

Fig. 3. Melted weld surface

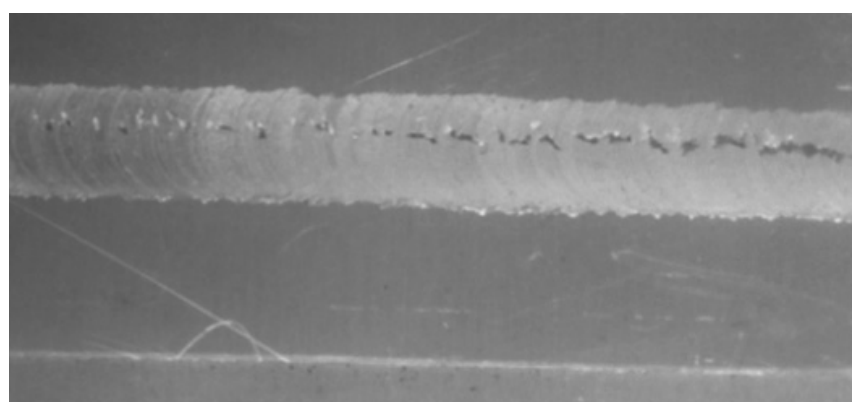

Rys. 4. Nieciągłości liniowe zgrzeiny

Fig. 4. Linear discontinuities of a weld

Na ciepło procesu możemy również wpływać siłą docisku narzędzia do łączonych elementów podczas procesu zgrzewania. Nie można jednak dowolnie manipulować tym parametrem. Stosowanie zbyt małej siły docisku może skutkować powstaniem połączenia adhezyjnego charakteryzującego się znacznie mniejszą wytrzymałością, natomiast zbyt duża siła powstawaniem wklęsłego lica zgrzeiny oraz wypływek [7]. Trzecim, równie niekorzystnym zjawiskiem związanym z siłą docisku jest jej nierównomierność. Przejawia się ona powstaniem zgrzeiny o różnej szerokości (rys. 5).

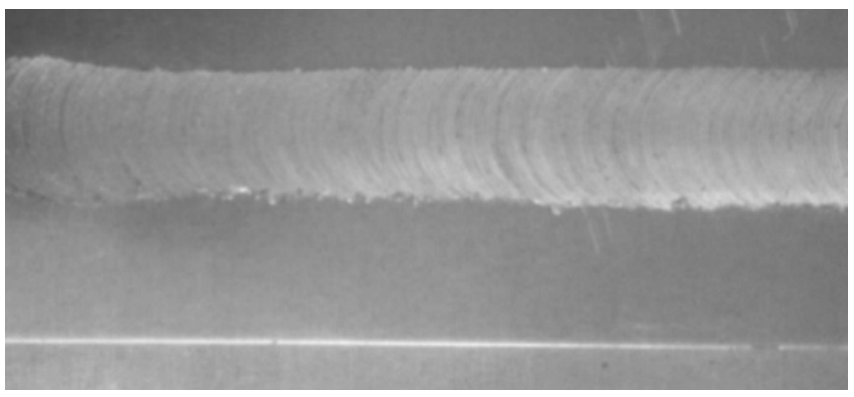

Rys. 5. Nierównomierna szerokość zgrzeiny

Fig. 5. Uneven weld width 


\section{Uchwyt podgrzewający}

W celu aplikacji dodatkowego źródła ciepła zastosowano uchwyt z płytą podgrzewającą elementy zgrzewane oraz instalację sterowaną za pomocą sterownika PLC LOGOV8 [5]. Uchwyt do zgrzewania tarciowego z przemieszaniem materiału zgrzeiny (rys. 6) składa się z kilku zasadniczych elementów, do których należy:

- podstawa,

- płyta grzejna wraz elementami grzejnymi oraz czujnikami temperatury,

- łapy dociskowe,

- ceowniki dociskające zgrzewane blachy.

Zasilanie układu podgrzewającego odbywa się za pośrednictwem transformatora, którego celem jest obniżenie napięcia z sieci trójfazowej (400 V) na 48 V. W płycie grzejnej umieszczono rezystancyjne czujniki temperatury Pt100. Zmiana rezystancji czujników, wynikająca ze zmian temperatury, jest modyfikowana przez przetwornik temperatury CP-03 na sygnał napięciowy o zakresie $0 \div 10 \mathrm{~V}$, informującym o aktualnym stanie temperatury z dokładnością do $5^{\circ} \mathrm{C}$. Tak przetworzone sygnały napięciowe są podłączone do wejść analogowych sterownika PLC Siemens LOGOV8. Sterownik ten jest zaopatrywany w energię elektryczną przy pomocy zasilacza Siemens 230/24 AC (rys. 7). Architektura programu sterownika PLC powstała przy użyciu programu Logo Soft Comfort v8. Zadaniem programu jest sterowanie wyjściami przekaźnikowymi, tak aby przy temperaturze odczytywanej z czujników Pt100 mniejszej niż zadana, załączały się styczniki LC1D12 Schneider. Zwierają one odpowiednie obwody grzejne ze źródłem zasilania. Układ zaprojektowano, tak aby możliwe było płynne sterowanie temperaturą [5].

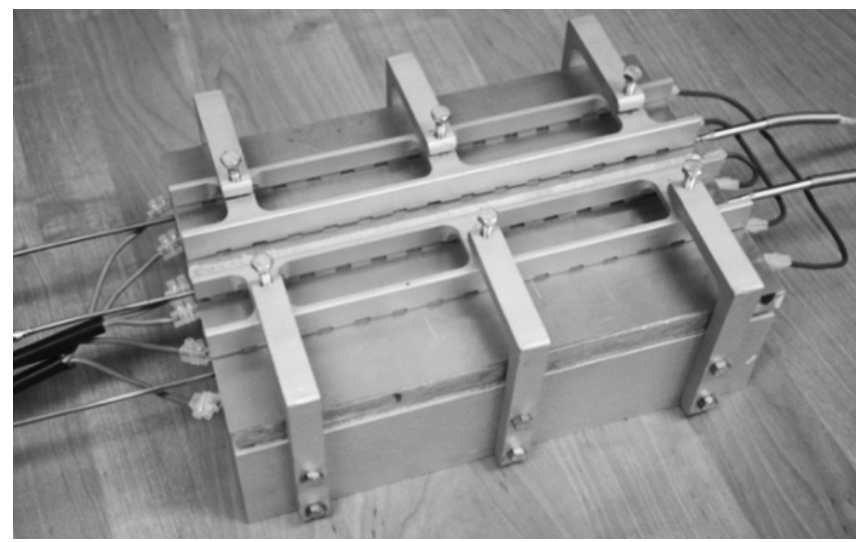

Rys. 6. Uchwyt do zgrzewania metodą FSW z płytą grzejną [5] Fig. 6. FSW welding handle with heating panel [5]

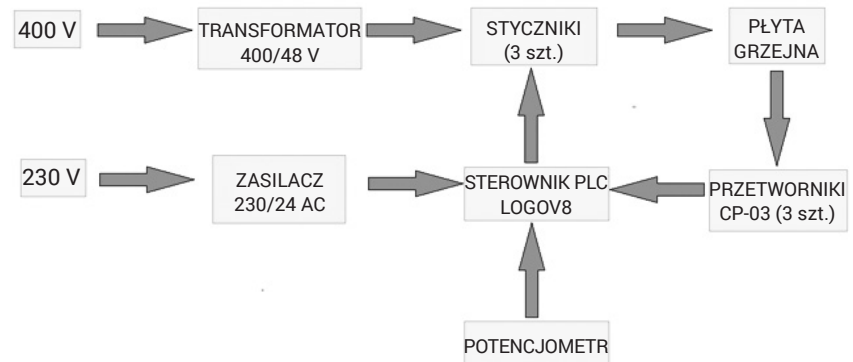

Rys. 7. Schemat blokowy instalacji podgrzewającej Fig. 7. Block diagram of heating installation

\section{Przebieg próby zgrzewania}

Ze względu na stosowanie w lotnictwie połączeń elementów zakładkowych zgrzewaniu poddano blachy grubości 1 mm ze stopu 2024 T351 zgodnie z rysunkiem 8 .

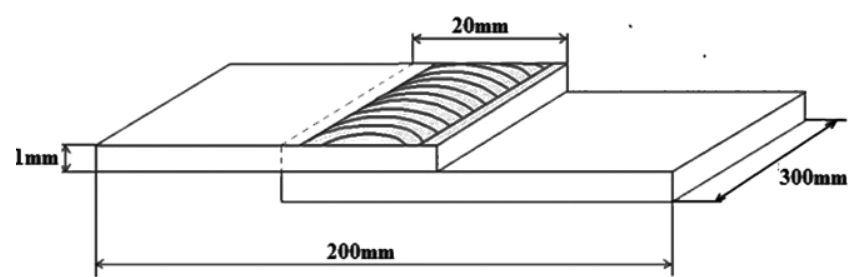

Rys. 8. Schemat wykonywanego złącza

Fig. 8. Scheme of the joint creation

Jako odpowiednie do zgrzewania tego rodzaju blach zastosowano narzędzie Schulter $\mathrm{RH}-10 / 5-\mathrm{S}-\mathrm{O}$ (rys. 9). W celu uniknięcia powstawania wypływek, proces zgrzewania przeprowadzano przy kącie pochylenia narzędzia równemu $2^{\circ}$.

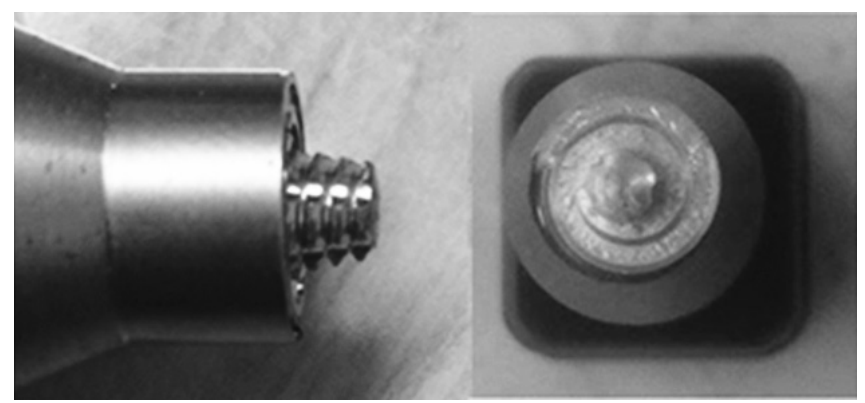

Rys. 9. Narzędzie Schulter RH-10/5-S-O

Fig. 9. Schulter $\mathrm{RH}-10 / 5-\mathrm{S}-\mathrm{O}$ tool

\section{Rozkład temperatury}

Podczas zgrzewania blach bez podgrzewania zarejestrowano proces rozchodzenia się ciepła, co przedstawiono na rysunku 10. Na zdjęciach z kamery termowizyjnej widać, jak powoli nagrzewa się narzędzie. Ma to bez wątpienia wpływ na własności powstałego złącza.

Podczas zgrzewania tarciowego z przemieszaniem temperatura stabilizuje się dopiero po wykonaniu $100 \mathrm{~mm}$ zgrzewu. Temperatura dla parametrów zgrzewania równych S1300 i F300 wynosiła $285^{\circ} \mathrm{C}$ (rys. 11).

Następnie wykonywano próby zgrzewania podgrzewając uchwyt do temperatury równej $160{ }^{\circ} \mathrm{C}$. Efektem tego było uzyskanie wyższej temperatury procesu, która wynosiła $345^{\circ} \mathrm{C}$ (rys. 12).

W początkowej fazie zgrzewania z zastosowaniem podgrzewania zarejestrowano temperaturę równą $291^{\circ} \mathrm{C}$.

\section{Własności wytrzymałościowe}

Z blach w miejscach, w których zanotowano ustabilizowaną temperaturę wycięto próbki szerokości 12,5 mm, a następnie przystąpiono do badań wytrzymałościowych na maszynie Zwick Roell. Na tej podstawie stwierdzono, żenajwyższe własności wytrzymałościowe zgrzanych blach bez podgrzewania uzyskuje się przy prędkości posuwowej równej $300 \mathrm{~mm} / \mathrm{min}$. W tablicy I przedstawiono wyniki wartości siły zrywającej dla różnych prędkości obrotowych.

Tablica I. Własności blach zgrzewanych bez podgrzewania Table I. Properties of welded sheets without preheating

\begin{tabular}{|c|c|c|c|}
\hline & $\begin{array}{c}\text { Prędkość obroto- } \\
\text { wa [obr/min] }\end{array}$ & $\begin{array}{c}\text { Prędkość posu- } \\
\text { wowa [mm/min] }\end{array}$ & $\begin{array}{c}\text { Wartość siły } \\
\text { zrywającej [kN] }\end{array}$ \\
\hline 1 & S800 & F300 & 1,98 \\
\hline 2 & S1300 & F300 & 2,88 \\
\hline 3 & S1500 & F300 & 2,50 \\
\hline
\end{tabular}



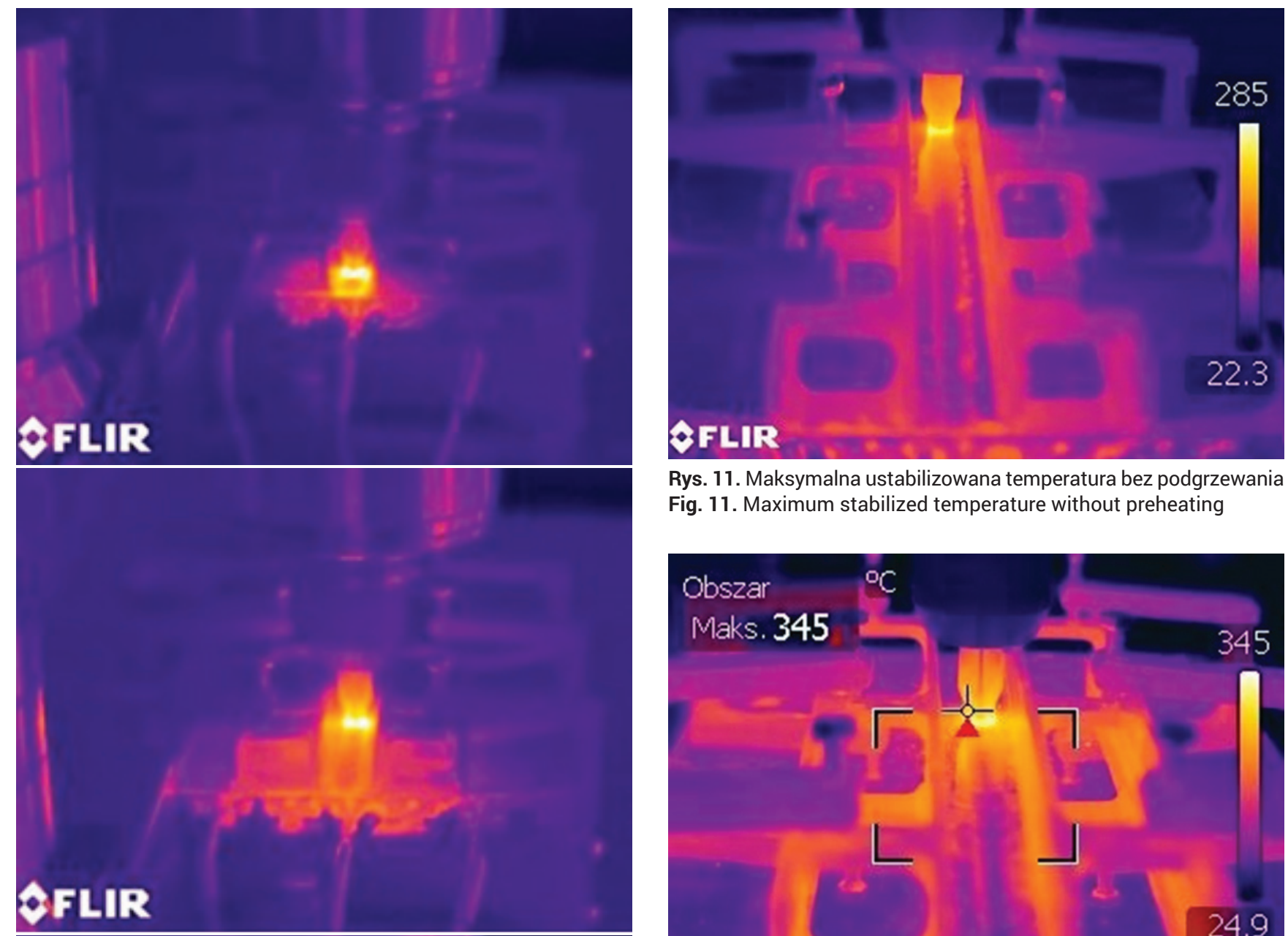

Rys. 11. Maksymalna ustabilizowana temperatura bez podgrzewania Fig. 11. Maximum stabilized temperature without preheating

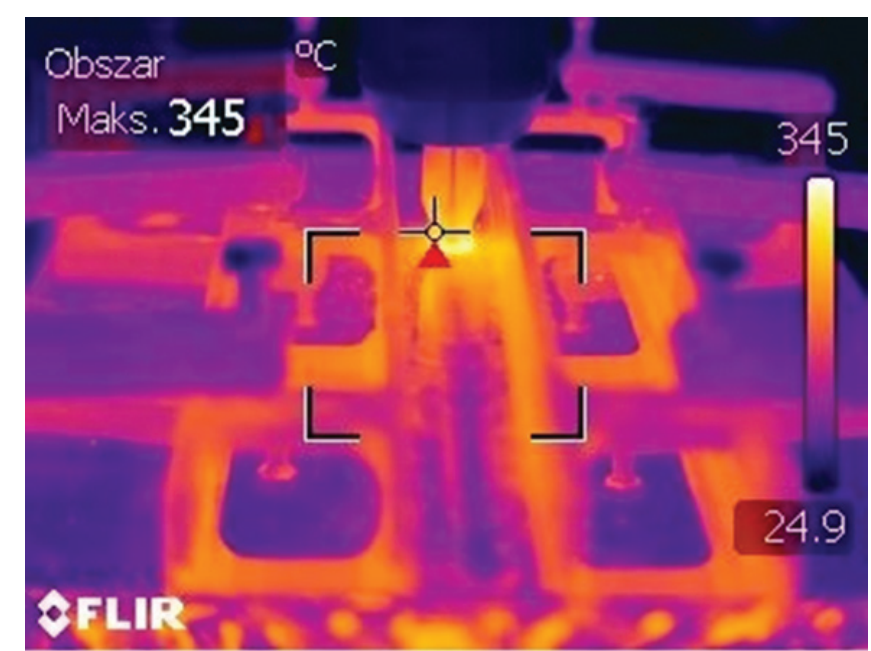

Rys. 12. Ustabilizowana temperatura podczas zgrzewania z podgrzewaniem

Fig. 12. Stabilized temperature during welding with preheating
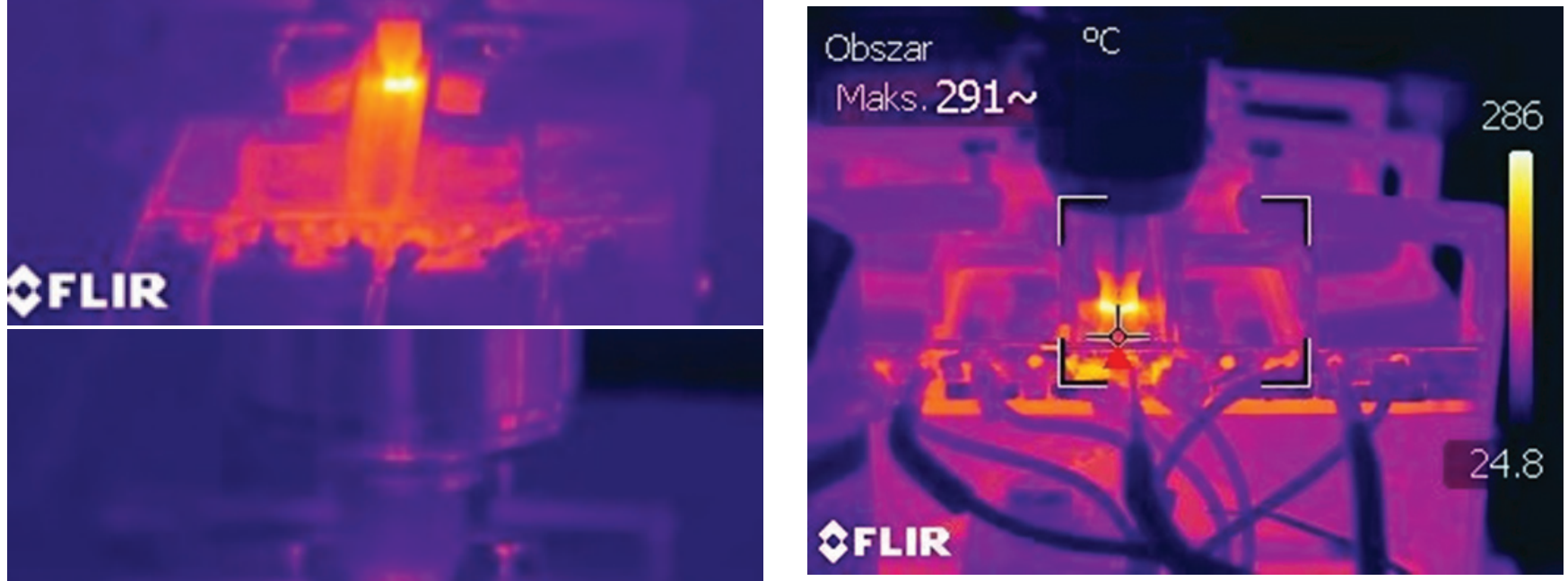

Rys. 13. Temperatura w początkowej fazie zgrzewania z podgrzewaniem

Fig. 13. Temperature in the initial stage of welding with preheating

W celu ukazania wpływu podgrzewania na własności wytrzymałościowe złącza wykonano połączenia podgrzewając uprzednio uchwyt, na którym przeprowadzono proces spajania. Wyniki pomiarów umieszczono w tablicy II.

W celu oceny efektywności połączenia mierzonej jako stosunek wytrzymałości materiału ze zgrzeiną do wytrzymałości materiału rodzimego próbie rozciągania poddano próbkę

Rys. 10. Rozchodzenie się ciepła podczas zgrzewania metodą FSW Fig. 10. Heat propagation during FSW welding 
o przekroju poprzecznym 1 x 12,5 mm. Blacha o takim przekroju przeniosła siłę rozciągającą równą $5,7 \mathrm{kN}$. Zestawienie wykresów próby rozciągania próbek zgrzanych z oraz bez zastosowania podgrzewania, a także litego materiału przedstawiono na rysunku 14.

Tablica II. Własności blach zgrzewanych z zastosowaniem podgrzewania

Table II. Properties of welded sheets with preheating

\begin{tabular}{|c|c|c|c|c|}
\hline & $\begin{array}{c}\text { Prędkość } \\
\text { obrotowa } \\
\text { [obr/min] }\end{array}$ & $\begin{array}{c}\text { Prędkość } \\
\text { posuwowa } \\
{[\mathrm{mm} / \mathrm{min}]}\end{array}$ & $\begin{array}{c}\text { Temperatura } \\
\text { podgrzewa- } \\
\left.\text { nia [ }{ }^{\circ} \mathrm{C}\right]\end{array}$ & $\begin{array}{c}\text { Wartość siły } \\
\text { zrywającej } \\
{[\mathrm{kN}]}\end{array}$ \\
\hline 1 & $\mathrm{~S} 600$ & $\mathrm{~F} 300$ & 160 & 1,64 \\
\hline 2 & $\mathrm{~S} 800$ & $\mathrm{~F} 300$ & 160 & 4,26 \\
\hline 3 & $\mathrm{~S} 1300$ & $\mathrm{~F} 300$ & 160 & 3,68 \\
\hline 4 & $\mathrm{~S} 600$ & $\mathrm{~F} 500$ & 160 & 2,61 \\
\hline 5 & $\mathrm{~S} 800$ & $\mathrm{~F} 500$ & 160 & 3,22 \\
\hline 6 & $\mathrm{~S} 1000$ & $\mathrm{~F} 500$ & 160 & 3,80 \\
\hline 7 & $\mathrm{~S} 1300$ & $\mathrm{~F} 500$ & 160 & 3,61 \\
\hline
\end{tabular}

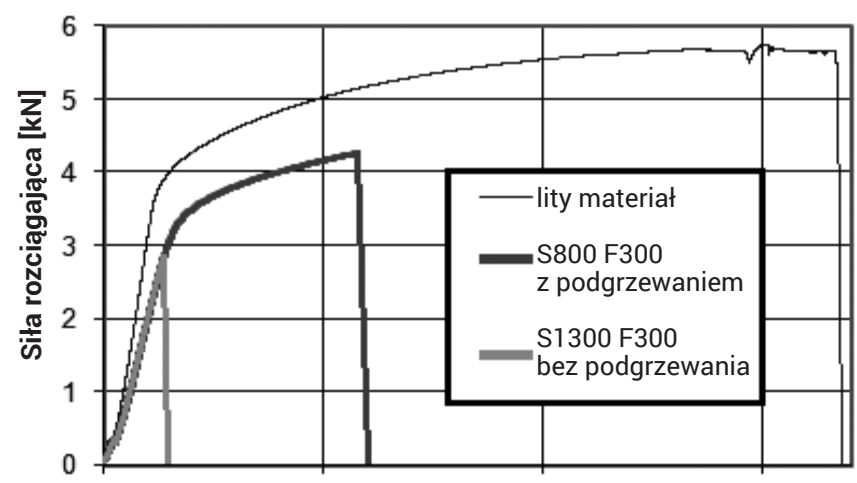

Wydłużenie [mm]

Rys. 14. Wykresy próby rozciągania blach zgrzanych metodą FSW Fig. 14. Graphs of tensile tests of sheets welded with the FSW method

\section{Charakterystyka miejsc zerwania}

Próbki zerwane na maszynie wytrzymałościowej różniły się znacząco pod względem miejsca zerwania. Blachy zgrzane bez podgrzewania zrywały się w strefie cieplno-plastycznej. Zerwaniu ulegała część mająca bezpośredni kontakt z częścią oporową narzędzia (rys. 15). Blachy zgrzane z zastosowaniem podgrzewania niszczyły się, natomiast w strefie zmieszania, w miejscu, gdzie pin mieszał materiał obu blach (rys. 16).

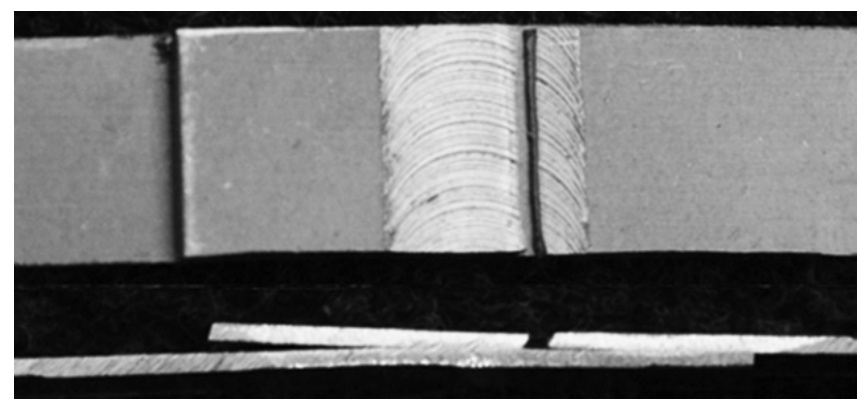

Rys. 15. Widok miejsca zerwania próbki zgrzanej bez zastosowania podgrzewania

Fig. 15. View of the place where the weld was broken without preheating

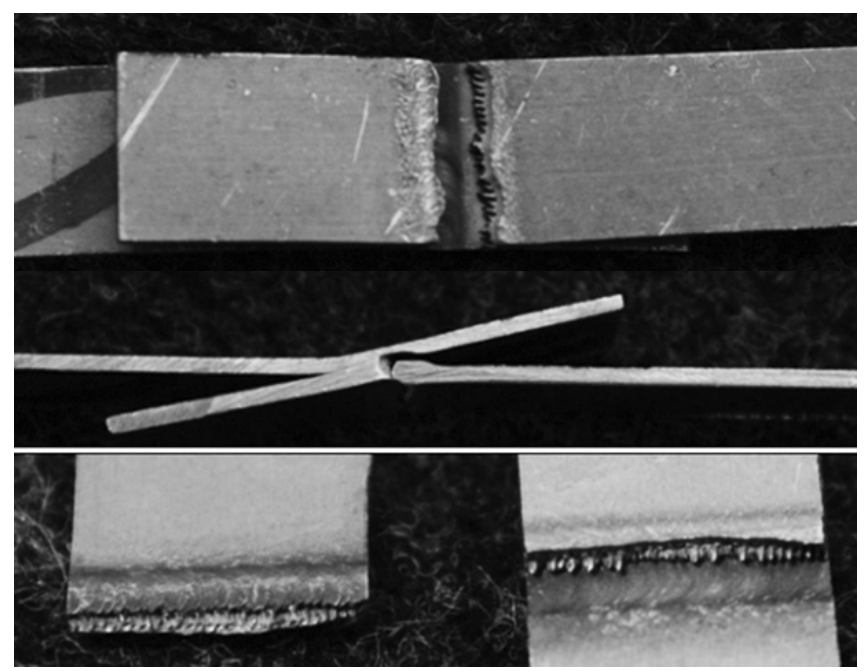

Rys. 16. Widok miejsca zerwania próbki zgrzanej z zastosowaniem podgrzewania

Fig. 16. View of the place where the weld was broken with preheating

\section{Wnioski}

Na podstawie wykonanych badań można stwierdzić, że zastosowanie podgrzewania w procesie zgrzewania cienkich blach, wpływa korzystnie na własności wytrzymałościowe złącza. Temperatura, którą można uzyskać bez podgrzewania jest zbyt niska. Zastosowanie podgrzewania podwyższa tą temperaturę, co przejawia się znacznym wzrostem wytrzymałości złącza. Blachy zgrzane w podwyższonej temperaturze ulegają zniszczeniu w strefie zmieszania. Na zerwanych próbkach widać charakterystyczne ząbki, które obrazują proces mieszania materiału. Blachy, które były poddane zgrzewaniu nie zostały uprzednio oczyszczane z warstwy tlenkowej, co mogło dodatkowo obniżyć wytrzymałość złącza. Wyniki uzyskane podczas zgrzewania z zastosowaniem podgrzewania świadczą o tym, że rozwiązanie takie jest korzystne nie tylko ze względu na mniejsze odkształcenia spajanych elementów, ale również pozwala na zminimalizowanie zużycia narzędzia. Blacha podgrzana wstępnie nie musi być już w tak dużym stopniu nagrzewana przez narzędzie, a co za tym idzie możliwe jest zastosowanie mniejszych prędkości obrotowych. Zwiększanie prędkości posuwowej zmniejsza ilość generowanego ciepła, tak więc podgrzewając zgrzewane elementy możemy przyspieszyć proces spajania. Dodatkowo, zastosowanie podgrzewania prowadzi do polepszenia własności plastycznych materiału. Stosunek wytrzymałości blachy litej (bez zgrzeiny) do blachy zgrzanej zakładkowo z zastosowaniem podgrzewania jest wysoki i sięga $75 \%$. Uzyskanie takiego wyniku pozwala uznać, że złącze zostało wykonane poprawnie. Próbki zgrzane bez podgrzewania do momentu zerwania wydłużyły się tylko o 1,4 mm, natomiast z zastosowaniem podgrzewania aż o 5,8 mm, co widać na wykresach próby rozciągania. Ogólny przebieg tych wykresów jest bardzo podobny do wykresu rozciągania blachy litej (niepoddanej procesowi spajania). Świadczy to o tym, że ciepło wydzielone podczas procesu zgrzewania z zastosowaniem podgrzewania wpłynęło pozytywnie na złącze. 


\section{Literatura}

[1] Dymek S.,Kalemba I., i Blicharski M.: Friction stir welding of aluminium 7136-T76511; Science and Technology of Welding and Joining; 2008.

[2] Kalemba I.: Mikrostruktura i własności połączeń stopów aluminium wykonanych metodą zgrzewania tarciowego z mieszaniem materiału zgrzeiny; rozprawa doktorska; Kraków 2010.

[3] Kocańda D., Góra A.: Nowe technologie łączenia tarciowego metali; Biuletyn WAT; 2010, Tom LIX, 2.

[4] Lityńska L., Braun R., Staniek G., Dalle Donne C., Dutkiewicz J.: TEM study of the microstructure evolution in a friction stir-welded AlCuMgAg alloy; Materials Chemistry and Physics, 81, 2003.
[5] Ochałek K.: Zgrzewanie tarciowe z przemieszaniem blach cienkościennych; Przegląd Mechaniczny, 1/ 2017.

[6] Pietras A., Zadroga L.: Rozwój metody zgrzewania tarciowego z mieszaniem materiału zgrzeiny (FSW) i możliwości jej zastosowania; Biuletyn Instytutu Spawalnictwa, 5, 2003.

[7] Pietras A., Zadroga L., Łomozik M.: Charakterystyka zgrzeiny utworzonej metodą zgrzewania z mieszaniem materiału zgrzeiny (FSW); Biuletyn Instytutu Spawalnictwa, 47, 2003. 